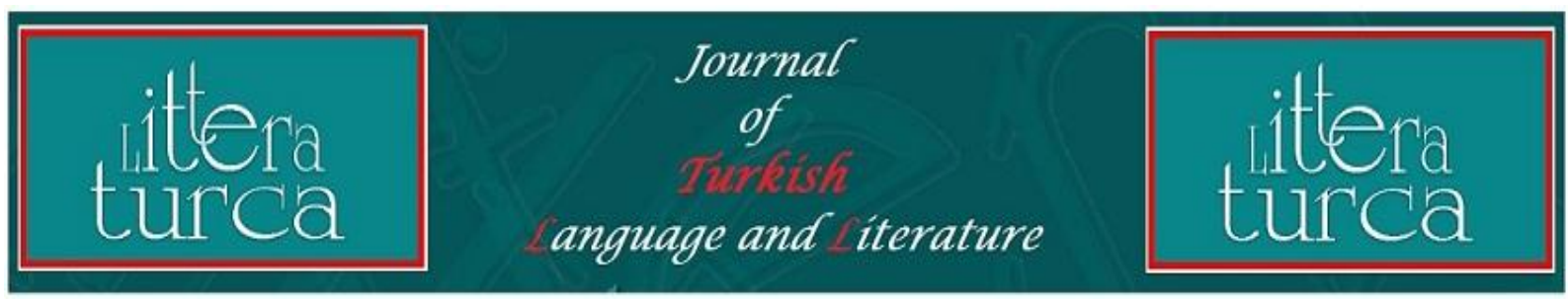

\title{
DEDE KORKUT HIKÂYELERI’NDE KÜLTÜREL BELLEK BAĞLAMINDA GELENEKLER
}

\author{
Fevziye ALSAÇ
}

Özet

\begin{abstract}
Halk edebiyatı ürünleri, anlatı düzleminde ait olduğu milletin maddî ve manevî kültür değerlerini ihtiva eder. Oğuz toplumunun destanlaşan hikâyesi olan Dede Korkut Hikâyeleri, Türk milletinin değerlerini, özlemlerini duygu ve düşüncelerini yansıtan bir yapı bütünlüğüne sahiptir. Halk edebiyatı için sonsuz bir zenginliğe sahip olan Dede Korkut Hikâyeleri'nde gelenekler, kültürel belleği canlı tutan bir yapıyla edebiyatımızın baş tacı eseridir. Dede Korkut Hikâyeleri'nde gelenekler, millî kültürle şekillenmiş ve yaşam tarzıla kodlaşmıştır. Gelenek, davranışın alışkanlık haline gelmesiyle oluşur. Kültürel bellek; kimlik, hatırlama, süreklilik ve yeniden üretme üzerine kuruludur. Dede Korkut Hikâyeleri'nde davranış haline gelen gelenekler; millî kimliği hatırlatma, süreklilik gösterme ve anlatılarda yeniden üretilme bağlamıyla kültürel belleği canlı tutar. Bu çalışmada Dede Korkut Hikâyeleri'ndeki kültürel bellek kodları olan gelenekleri hikâyelerden örneklerle değerlendirdik.
\end{abstract}

Anahtar Kelimeler: Dede Korkut Hikâyeleri, kültür, gelenek.

\section{DEDE KORKUT'S STORIES TRADITIONS IN THE CONTEXT OF CULTURAL MEMORY}

\begin{abstract}
Folk literature products contain the material and spiritual cultural values of the nation to which it belongs on the narrative level. Dede Korkut Stories, the epic story of the Oguz community, is a structure that reflects the values, aspirations and feelings of the Turkish nation. In Dede Korkut's Stories, which have an infinite richness for folk literature, traditions are the work of the chief crown of our literature with a structure that keeps the cultural memory alive. In Dede Korkut's Stories, traditions are shaped by national culture and coded in a lifestyle. Tradition occurs when behavior becomes a habit. Cultural memory is built upon identity, recall, continuity and reproduction. The traditions that have become behavior in Dede Korkut's Stroies keep the cultural memory alive in the contexts of reminiscence of the national identity, continuity and remake of the stories when retold. In this study, we evaluated the traditions of cultural memory codes in Dede Korkut Stories with examples from stories.
\end{abstract}

Key words: Dede Korkut Stories, culture, tradition.

\footnotetext{
${ }^{1}$ Toki Yazıkonak Ç.P.A. Lisesi, Türk Dili ve Edebiyatı Öğretmeni, fevziyealsac_23@hotmail.com
}

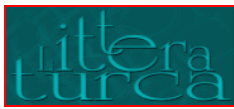

Journal of Turkish Language and Literature

Volume:4, Issue:1, Winter 2018, (17-35)

Doi Number: 10.20322/littera.378019 


\section{Giriş}

Gelenek, ait olduğu kültürün taşıyıcısı ve toplumun değerler dünyasını tecrübeyle ortaya koyan bir koddur. Gelenekler, birbiriyle uyumlu ve sürekliliği olan toplumsal uygulamalardır. Yıllar boyunca süreklilik ve ortak paylaşımla doğan gelenekler, kültürel bir mekânı sözlü gelenek içinde geleceğe taşır. "Gelenek sözlü anlatılar bağlamında 'ortak akıl' ile ilintilidir. 'Ortak akıl'dan söz eden, bizim olan, bize gönderme yapan özel ve özgül bir kültürden söz eder. 'Bu doğrultuda gelenek, 'zamanın ve tarihin kültürel bir gösterimi” (Aktulum 2013: 15) şeklinde ifade edilir. Gelenekler zaman, tarih ve kültürel anlamın devredilerek canlandırılma biçimi olarak kültürel belleğin alanına girer. Kültürel bellek bağlamında yorumlama ve hatırlama işlevini gören edebî metinler ve törenler yorumlayıcı okumaya dönüşür. Yorumlayıcı okumada, edebî metin ve törenler uzun bir uygulama sonucu oluşan gelenekleri kültürel kodlarla sembolleştirir. Her kültür, sosyal boyutta ve zaman boyutunda milleti birleştiren, bağlayıı bir yapı olarak gelenekleri yaratır. "Ortak deneyim, beklenti ve eylem mekanlarından bir 'sembolik anlam dünyası' yaratarak, birleştirici ve bağlayıcı gücüyle güven ve dayanak imkanı sağlayarak insanları birbirine bağlar. " (Assman 2001: 21) Geleneklerin aktarımını sağlayan törenler, tekrar edilme yönüyle bağlayıcılık ve kalıcılık sağlar. Bu bağlamda edebî metinler ve törenler, tekrarlama ve canlandırma işleviyle geleneği canlı tutar. Dönemler ve insanlar farklı olsa da yaşananlar ortak bir yaşamın göstergeleri olan kültürel belleği canlı tutan geleneklerdir. Ortak yaşam alanının sınılları hep aynı şekilde çizilir ve o milletin kültürünün izlerini taşır. Bir milletin kültürel kimliğini oluşturan edebî eserler aracılığıyla o milletin tarihi, dili, inanışları, gelenekleri, görenekleri, ülküleri, kısacası kültürel belleğine dair önemli ipuçları elde edilir. Destan ve hikâye özelliğiyle sözlü gelenek içinde yoğrulmuş zengin folklorik malzeme içeren Dede Korkut Hikâyeleri, Türk kültürü içinde yer alan geleneklerin kültürel belleği olma işlevine sahip anlatılardır. Destanlar ait oldukları toplumun kimliğini taşıyan bir karaktere sahiptir. Hikâyeler, günlük olayların aşk ve kahramanlık ile yoğrulmasıyla oluşmuş anlatılardır. Türk kültürünün canlı hafızası, Dede Korkut Hikâyeleri destan ve hikâye özelliklerinin her ikisini de taşır. Millet olma bilincinin ülkü değerler düzeyinde anlatıldığı destansı Dede Korkut Hikâyeleri, kültür mozağimizin kıymetli bir eseridir. Türk edebiyatında destandan hikâyeye geçişin ilk örneği olan hikâyelerde; Oğuz boyunun komşularıyla olan ilişkileri, aile ve toplum yapısı, devlet yönetimi, kahramanlık ve aşk gibi birçok konu işlenmiştir. Hikâyelerin ana eksenini yiğitlik ve kahramanlık oluşturur.

"Dede Korkut öykülerinin ilginç özellikleriyse, ona bakışımızı daha da yoğunlaştırıyor: insanlığın ilk ürünlerinden olan destan ve masaldan tutunuz, bugünkü öykü, roman ve oyuna; tarihsel gerçeklerden tutunuz, toplumsal, töresel, ruhsal, dilsel... kısaca insanbilimi ilgilendiren tüm konularda, birçok örneği kapsıyor bu öyküler." (Ünlü 1994: 175)

Temaların birleştirici özelliği Türk toplumunun millî kimliğini içeren kültürel bellek kodları olan gelenekleri/değerleri her bir hikâyede yeniden hatırlatma, yaratma ve devam ettirme özelliğidir. İçerdiği kültürel mirasla baş tacı eserimiz olan bu anlatılar, kültürel bellek mekânı özelliğine sahiptir. Göçebe Türk halkının kültürel kodlarını gelenek ve göreneklerini, inanışlarını anlatan bu hikâyeler, Oğuz Türklerinin yaşam tecrübesi ve inanışlarını ihtiva eden söylemsel göstergelerden oluşur. Hikâyeler ayrı ayrı olsa da onlar Türk

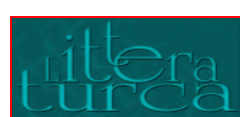

Journal of Turkish Language and Literature 
halkının soylu geçmişini, yaşam tarzını, gelenek ve göreneklerini, milli şuurunu, inançlarını şifreleyen bir bütündür. Anlatılar, kahraman/kahramanlar aracılığıyla anlatı düzlemine oturan kültürel belleğin canlı tutulduğu bir mekândır. Gelenekler, yaşatılma ve devam ettirilme bağlamıyla ev/ocak kültünün devamını sağlayan kültürel mekânlardır.

Dede Korkut Hikâyeleri, Türk millî kimliğinin ortak bilinçdışı alanını oluşturan kültürel kodları hatırlatma ve yaşatma işleviyle değerini yeniler. Anlatılar bir bütün olarak soylu Türk tarihinin belgesi, geçmiş ve geleceği birleştirerek değerini sürekli artıran kültürel bir mirastır. Dede Korkut Hikâyeleri'nde halk kültürünü canlı bir sahne olarak gösteren gelenekleri şu alt başlıklar halinde belirleyebiliriz:

\section{Ak Sakallı/Saçlı Geleneği}

Ak sakkal, toplumun yol göstericisi ve kutsal değerleri bilge ve olgun kişi sıfatıyla kendinde toplayan kişidir. Atalar ruhuna sahip akıllı ve bilge kişi, ağ/ak sıfatıyla yıllanmış bir tecrübeyi ifade eder. Ata, baba ve dede anlamlarında kullanılan bu kavram; koruyuculuğu, bilgililiği ve soyluluğu ifade eder. Ak sakallı, ağ saçlı kişi yüce birey arketipini sembolize eden ve kahramanın başarıya ulaşmasında ona rehberlik eden yüce bilicidir. "Bu yaşlı adam, dünyamız gibi iki milyon yıl boyunca insan yaşamını tüm acıları ve nesneleriyle yaşamış, varoluşun ana imgelerini kendinde biriktirmiş ve evrensel deneyimi adına insan ruhunda bireysel bir durum oluşturan imgeleri yetkili kılmıştır." (Fordham 2004: 244) Türk milletinin yüce bireyi Dede Korkut/Korkut Ata, Oğuz halkının babası, atası ve bilicisidir.

Türk insanının deneyimleri, onun şahsında vücut bularak canlı kalır. Korkut Ata, bugünün insanına da yol gösteren atalar ruhunun yüce şahsiyetidir.

"Insanın tinsel doğumları için birer hareket kodu olan arketipler, ortak bilinçdışında biriken mitik enerji birikimini şimddileştirme/güncelleme ve derin bilinçdışı akıntılarını arketipsel semboller aracılığıyla bilince taşıma işlevleriyle öne çıkarlar." (Korkmaz 2016: 13)

Dedem Korkut/Korkut Ata, Oğuzların ak sakallı rehberi, yüce bireyidir. Bu ifadeler, Türk milletinin atası, dedesi olan yüce şahsiyetin sıfatlarıdır. Dede Korkut Hikâyeleri'ni okumaya başladığımız anda kendimizi Türk toplumunun göçebe hayatı içinde buluruz. Bu yaşamın anahtarı ağ sakallı vasfına sahip olan Dede Korkut'un elindedir. Kapılar açılır ve Hanlar Hanı Bayındır Han otağında beyleriyle sohbet ederken görülür. Giriş kısmında Dede Korkut'tan bahsedilirken Oğuz'un her müşkilini halleden kişi olduğu, Hz. Muhammed zamanına yakın bir dönemde yaşadığı anlatılır. Oğuz halkının her sıkıntısını olağanüstü güçleriyle halleder, kerametler gösterir. Kutsal ve bilge kişiliğe sahiptir. Gelecekten haber verir ve efsanevî bir kişilik gösterir.

"Hazreti Resul aleyhisselam zamanına yakın Bayat boyundan Korkut Ata derler bir er kopdu, Oğuzun ol kişi tamam bilicisiydi, Oğuzun içinde tamam velayeti zahir olmışıdı, ne derse olurdu. Gayipden dürlü haber söylerdi. Hak Taâlâ anun gönlüne ilham ederdi. Korkut

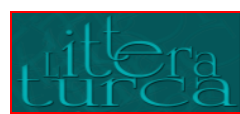

Journal of Turkish Language and Literature Volume:4, Issue:1, Winter 2018, (17-35) Doi Number: 10.20322/littera.378019 
Ata ayıtdı: Ahır zamanda hanlık gerü Kayıya değe, kimsene ellerinden almaya, ahır zaman olup kıyamet kopunca. Bu dedügü Osman neslidür, işde sürülüp gideyürür. Ve dahı nice buna benzer söz söyledi." (Gökyay 2007: 19)

Mukaddime kısmında Dede Korkut'un Oğuz halkı için taşıdığı kutsiyet uzun uzadıya anlatılır. Dede Korkut, Oğuz halkının atalar ruhunu taşıyan ulu rehberi ve yüce bireyidir. "Yüce Birey, toplumun değerlerinin kişiler düzlemindeki temsilcisidir." (Kanter 2005: 133) Yüce birey, kahramanın yol göstericisidir. Serüvenin başarıya ulaşmasında kahramanın destekçisi ve rehberidir. Dede Korkut bilge tipinin gücü olarak; alp tipini dönüştürür. “Bu nedenle Oğuz'un durması, toprağa konumlanması, eğlenmesi ve oturması ancak yüce birey arketipinin simgesi bilge tipi ile eyleme bağlı varolan alp tipinin bütünleşmesi ile mümkün olacaktır." (Korkmaz 2016: 19) Alp tipinin ihtiyacı olan bilgeliği ve aklı yüce birey arketipinin dönüşüm formlarından bir değer olan bilge tip ak sakkal rolüyle Dede Korkut kahramana kazandırır. Bamsı Beyrek'i ak sakallı bilge kişi olarak hayata hazırlar.

"Dede Korkut'un 'Sen insansın, hayvan ile musahip olmagıl!' diyerek ona kendi evinde/kendi içinde oturmayı öğretmesi, yani etkin ve bilinçli bir insanlaşma sürecini başlatması. Burada filogenetik birikimin, kişisel bilince kodlanması sayılan bir aktarım sürecinden de bahsetmek mümkündür. Birey, ait olduğu toplumun değerler dizgesini, yücebirey arketipi aracılığı ile edinmeye çalışır. " (Korkmaz 2016: 22)

Benlik bütünlüğüne ulaşmış, olgun kişi kimliğini kazanmış 'Yüce birey' atalar ruhunun temsilcisidir. Dede Korkut kimliğinin oluşmasında Şamanist ve İslâmî unsurlar bütünleşmiştir. Dedem Korkut, hem bir ozandır hem de manevî değerlerin taşıyıcısı olarak kerametler gösteren bir ermiştir. Bu kimliğin oluşmasında hikâyelerin geçiş dönemi eseri olması etkilidir. Eserin oluşturulduğu tarihle yazıya geçirildiği tarihin farklı olması iki inancın sentezini oluşturmuştur. Elinde kopuzu boy boylayan, soy soylayan Dede Korkut, eserdeki 12 öyküyü toparlayıp bir bütün olarak Türk milletinin destansı hayatını anlatan kişi olarak bilinmektedir. Şamanist inanç sisteminde kamlar ve ozanlar, toplumun yol göstericisi olma, hastalıkları tedavi etme, duaları ve kurbanları Tanrı'ya ulaştırma gibi misyonları üstlenmişlerdir. Dede Korkut, atalar ruhunun gelenekselleşen kültürel kodlarını geleceğe taşır; doğum, ad verme, eğlence, kutlama, evlilik, ölüm ve yas törenlerini kam/ozan kimliğiyle yönetir. Bu yönüyle hayatın her aşaması onunla anlam kazanır.

"Dede Korkut epiğinin hem anlatıcısı hem de öykü karakterlerinden biri olan bu erdemli ihtiyar, sorunları aklıyla çözmesi, yol göstermesi, geçiş dönemi oluşlarını (doğum, ad verme, statü belirleme vd.) onaması bakımından, bütün anlatıların vazgeçilmez bilge kişisidir. Bu haliyle Dede Korkut, insan varlığından çok temsil ettiği değerler bütünüyle dikkati çeker. Çünkü Dede Korkut, binlerce yıllık bir oluş deneyimine ait bilgi birikiminin insanlaşmış, kişileşmiş biçimidir ve dünyada varolmak isteyen Oğuz toplumu için yaşamsal öneme sahiptir." (Korkmaz 2016: 14-15)

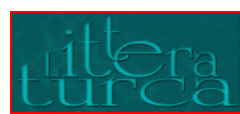

Journal of Turkish Language and Literature 
Ak sakal; bilen, bilgili, akıllı, yüce ve saygı değer kişiler için kullanılan bir terimdir. Ak sakal kavramı günümüzde de Türk dünyasında kullanılan bir terimdir. Ağ sakkal/saç, yaşlılık anlamında değil; bilgelik, akıl, yücelik, saygı ve tecrübe anlamındadır. Hikâyelerde bu sıfat Dede Korkut'a verilen 'atalar ruhuyla' bağlantılı kutsal bir söylemdir. Dede Korkut her konuda bilgili, yol gösterici, toplumu birbirine bağlayan kişidir. Dualar eder, kahramanlara isim verir.
“Dede Korkut Hikâyeleri'nde, Korkut'un kabile ve halk içinde türlü yönlerden sahip olduğu mevkiyi görüyoruz. Korkut Ata'nın göze çarpan niteliklerinden biri de onun bir halk bilgesi oluşudur. Onun bu yanı hem yeri ve sırası geldikçe verdiği öğütlerde hem de söylediği hikmetlerde ortaya çıkar. Nitekim tutsak olan babasını kurtarmak için yola çıkan Yegenek gördüğü düşü anlatırken "Ak sakalıı Dede Korkut'tan öğüt aldım.” (Gökyay 2007: 818) der.

Toplumun sözcüsü olan ve sözüne hürmet edilen Dede Korkut, Tepegöz ile pazarlık eder ve Beyrek'e kız ister. Ağ sakkal yüce ulu kişinin sözüne değer verilir. Kutadgu Bilig, Divanü Lugati’t- Türk gibi kaynaklarda da ağ sakallı yüce kişilerin Türk toplumundaki önemi dikkate değerdir. Tarihin ilk dönemlerinden günümüze kadar ilim erbabına verilen değer değişmemiş köklü bir gelenektir. Dede Korkut, Oğuzların birlik içinde yaşamasını sağlayan ölümsüzleşmiş bir şahsiyettir. Türk insanının atasına olan saygı ve sevgisiyle onun şahsına mal olmuş efsaneler teşekkül etmiştir.

\section{Sosyal Hayatı ve Milî Bilinci Oluşturan Gelenekler}

Hikâyelerde, Orta Asya'dan gelen Oğuzların Kayı boyunun, yerleştiği bölge olarak Azerbaycan ve Doğu Anadolu coğrafyası öne çıkar. Oğuzların Rum, Gürcü ve Abazalarla komşu oldukları ve onlarla olan mücadelelerinin destanlara konu olduğu bilinmektedir. Yer isimlerinden özellikle Trabzon, Bayburt illerinin geçmesi, çeşitli mekânların isimlerinin zikredilmesi bu bilgileri doğrular. Anlatılarda geçen ifadeler avcı-göçebe kültürün yaşam tarzı olan hayvancılığa dayanan bir hayatla şekillenir. Bozkır hayatının gereği olan savaşçılık ve avcılık, belli yeteneklere sahip olmayı gerekli kılar. Toplumun her ferdi bir askerdir; at binme ve kılıç kuşanmada ustadır. Düşmanların çokluğu ve göçebe yaşam şartları her ferdin bu özelliklere sahip olmasını gerektirir. At, göçebe yaşam tarzında evcilleştirilen ilk hayvan olarak kahramanla bütünleşir ve ikisi arasında özel bir bağ oluşur. At, destan ve masal anlatılarında kahramanın en önemli yardımcısı ve destekçisidir.

"Dede Korkut destanlarında, kahramanın atı, gelecek felaketi ve düşmanın yaklaştığını sezerek sahibine haber verir: 'Begil'in atı Al aygır kaçan kim yağı kohusun alsa ayağın yere dögeridi, tozu göge çıkarıdı.' Uşun Koca Oğlu Segrek uyuyakalmışken, meger yigit aygır bineridi. Hanum, at kulağı sak olur, çeküneni oğlanı uyardı." (Gökyay 2007: 1182)

Atın da hünerli olması sahibi için önemlidir. 'At işlemese er övünmez, hüner atındır.' sözü ile sahibinin başarılı olması atın maharetine bağııdır, ifadesi atın ve sahibinin yiğitliğini ve kültürümüzdeki önemini belirtir.

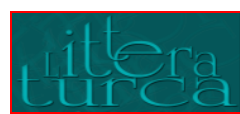

Journal of Turkish Language and Literature 
Kadın ve erkek, sosyal hayat içinde birbirinin destekçisidir ve bu ayırıcı özellik aile olmanın gereğidir. Eşler arasında karşılıklı sevgi ve saygı ailenin devamını sağlayan birleştirici ve önemli bir gelenektir. Kadın, Türk toplumunda eşit haklarla ve savaşçı, mücadeleci bir karakterle geleneksel bir role bürünür.

"Sürü sahibi ve yağmacı göçebe yapılarda insan faktörü ve dolayısıyla kadın insan üreticisi olarak önemlidir. Ayrıca, erkeklerin savaşta ve avda olduğu süreler boyunca kadın, topluluğu, çocukları, barınakları, yiyecekleri ve sürüleri korumaktan sorumludur. Hayvanlardan elde edilen gıda maddelerinin üretimi, denetim ve saklanması; giysi ve barınak yapımı, daha önemlisi çocukların beslenme, bakım ve sosyalizasyonu kadına aittir. Güç tabiat şartlarında ve çetin göçebe hayatı içinde kadınında erkek kadar güçlü, mücadeleci, cesur ve atak olması gerekir..." (Türköne 1995: 128)

Cinsiyet ayrımı ve kölelik görülmeyen Türk toplumunda saygı kültürü ve bilinci egemendir. Geleneksel aile yapısı, anlatılarda kültürel bellek kodu olarak korunur. Toplumda her ferdin şahsını ve toplumunu temsil eden bir yeri vardır. Kadın ve erkek, aile içinde aynı değere sahiptir.

"Çin kaynakları, Türklerin kadın erkek, çoluk çocuk bir arada çalıştıklarını, birlikte ilkbahar ve sonbahar bayramlarını kutladıklarını, birlikte toylara, düğünlere, yaslara katıldıklarını anlatır. Buna dair ipuçlarını, Orhun Abideleri'nde de bulmak kabildir. Dede Korkut destanlarında, hanlarla hatunların şölenlere, yağmalı toylara, diğer toplantılara birlikte katıldığı anlatılır." (Eröz 2000: 27)

Eşler arasında kuvvetli bir muhabbet ve saygı vardır. Deli Dumrul'un eşi, Dede Korkut Hikâyeleri'ndeki diğer kadınlar gibi bir kez seven sevdiğine can bağışlayan ikisinin bir olduğu bilincine ulaşmış benliğini yüceltmiş bir kadındır. O, hikâyelerin diğer kadın kahramanları gibi eşine sevgi ve sadakatle bağlıdır. Atası ona, töre ve geleneklerini bu şekilde öğretmiştir.

"Ne dersin ne soylarsın?

Göz açup gördüğüm

Gönül verüp sevdüğüm

Koç yigidüm şah yigidüm

Tatlu damağ verüp soruşduğum

Bir yasdıgda baş koyup emişdügüm

Karşu yatan kara dağları

Senden sonra ben men neylerem..." ( Gökyay 2007: 117)

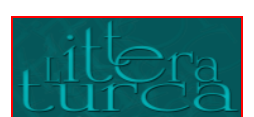

Journal of Turkish Language and Literature 
Kadın ve erkek ailenin oluşumunda eşit değerde görülür ve eşler birbirlerine sevgi ve saygıyla bağlıdırlar. Aile kutsaldır, eşler ve çocukları arasında karşılıklı sevgi ve saygı vardır. Ailenin bütünlüğü için çocuk önemlidir. Gelenekli bir toplumda çocuk ve aile sosyal hayatın belirgin bir konumlanmasıdır. Çocuksuzluk lanet olarak görülür. Dirse Han, Bay Büre Beg ve Bay Bican Beg çocuk özlemi çeker. Kısırca Yenge'nin adı çocuğunun olmamasıyla ilişkilidir; bu isim çocuğu olmadığı için verilmiştir.

Anne, kahraman için ve kutsal ve yüce varlığıdır. Salur Kazan 'ağ bürçekli' kadın-ana için savaşa girer. Tüm malından eşinden ve oğlundan vazgeçer ancak annesinden vazgeçmez; bu durum atanın/evin kutsal dayağı olan ananın kutsal sayıldığı bir toplumun köklü geleneğidir.

“Eski Türkler anneye 'ög' derlerdi. Bugünkü 'öksüz' sözümüzde buradan gelmektedir. Babadan sonra aileyi, anne temsil ederdi. Bunun için, ananın yeri, babanın diğer akrabalarından ileri olurdu. Babanın mirası, anneye değerdi. Çocukların, vasisi de o idi. Türk tarihinde kadınların, hükümdarların naibi olabilmeleri veya devlet içinde büyük bir söz sahibi olmaları da, bundan ileri geliyordu." (Ögel 1988: 247)

Kadının da aile kurumunda söz sahibi olması ve erkeğin en büyük destekçisi olması geleneksel Türk aile yapısını tasvir eder. “Dede Korkut'ta, 'başım tahtı, evim bahtı, kadınım, direğim, dölüğüm' diye anılan kadınlar, herhalde evde, ya baş kadın veyahut da tek kadınlar olmalı idiler." (Ögel 1988: 252) Aile olma ve bunun gerekleri kutsal görülen değerlerdir; bu bilinçle Boğaç Han, kendisini öldürmek isteyen babasını kurtarmaya gider. Erkek evlat ve baba arasında sevgi ve saygıya dayanan bir ilişki vardır. Baba ve oğlu yakınlaştıran, muhabbeti sağlayan eş ve kadın anadır. Segrek, kardeşi için kendini tehlikeye atar ve kardeşi Egrek'i kurtarmadan gerdeğe girmez. Aile ferdinin esaret altında olması kişi için büyük bir utançtır. Yegenek, tutsak olan babasını kurtarmayı onur meselesi yapar. Kahramanlar için namus önemli bir erdemdir. Uruz annesine etinden yemesini söyler; babasının namusu ona emanettir. Bir toplumun/milletin sosyal hayatı, tarihsel süreçle bağlantılı olarak köklü bir geçmişle şekillenen geleneklerin zenginliğini ortaya koyar. Dede Korkut anlatılarında, kahramanların olaylar karşısındaki davranış tarzları sosyal hayatla şekillenmiş geleneklerin kültürel mekânıdır. Millî hafızayı güçlendiren tecrübe ve yüce değerlerin taşıyıcısı olarak atalar tecrübesine dayanır.

Millet kavramı paylaşılan ortak değerlerden ve yaşamdan doğan bir birliktir. Anlatılarda sosyal devlet anlayışı görülür; hakan/bey bu bilinçle milleti birleştiren kişidir. Türk devlet yapısında tarih boyunca halkın memnun edilmesi ve ihtiyaçlarının karşılanması önemli görülmüştür. "Prof. Osman Turan da eski Türk devlet anlayışında, kağanın bütün kavmi için hukuk bakımından 'baba' durumunda görüldüğü, bundan ötürü de onun 'aç ve çıplak halkı doyurup giydirmek, az halkı çoğaltmak' ile yükümlü sayıldığını belirtmektedir." (Gökyay 2007: 1037) Hanlar hanı Bayındır Han ve diğer beyler Göktürk Yazıtları'ndaki Türk hükümdarları gibi aç görse doyurur, çıplak görse giydirir. Törenlere başta Hanlar Hanı Bayındır Han olmak üzere tüm Oğuz beylerinin hep birlikte katılma geleneği vardır. Kahramanlar, ferdî düşünceyle değil millet olma bilinci ile hareket eder. Sevinç ve üzüntü ortak bir şekilde paylaşılır. Hikâyelerde bağımsızlık önemlidir; esaret altında olmak kabul edilmez. Türk milletinin tarih

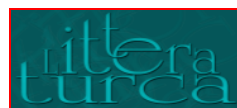

Journal of Turkish Language and Literature 
boyunca devleti yıkıldığında yenisini kurması bağımsızlığına verdiği değerdir. Birbirinden bağımsız hikâyelerin ortak noktası bireysel olarak gelişen macerada kahramanın düşmanını alt etmesi için bütün beyler birlik olmasıdır. Millet olmak birlikte ve büyük bir aile olmaktır. Salur Kazan'ın ailesini tutsak eden düşman karşısında Oğuz beyleri tek vücut olur. "Meger bu tarafda Oğuz begleri Kazanun kaziyesini işidüp Kazanun ardına düşmüşleridi. Bu mahalde kalın Oğuz begleri gelüp yetdiler. Hanum görelüm kimler yetdi:" (Gökyay 2007: 53) Oğuz beyleri düşmana karşı tek kuvvet olurlar ve birlikteliğin geleceğe kalmadaki en önemli değer olduğunu ortaya koyarlar. Millet olma, ortak bir paylaşım ve değerler dünyasıyla ifade kazanır. Türk insanı, her daim yöneticilerine/beylerine sadakatle bağlıdır. Salur Kazan'ın çobanı olan, Karaçuk çobanın, beyi Salur Kazan için canını ortaya atması millî bilince ve beylere duyulan saygı ve sevgiye güzel bir örnektir. Geleneğe bağlı olarak kişinin bireysel olarak canının önemi yoktur; devlet ve millet sevgisi her şeyin üstündedir. Devlet ve millet olma bilinci toplumun/milletin başı olan beye/hakana duyulan saygı ve sadakattir.

\section{Kopuz ve Ozanlık Geleneği}

Kopuz, Türk toplumunun millî çalgısıdır; köken olarak Orta Asya’ya uzanır. Kopuz, “Eski Türk Halk şairlerinin düğünler, törenler veya herhangi bir vesile ile şiirlerini okurken çaldıkları musiki aletidir. Eski şekli ile Altay Türkleri ve Kafkasya'da hala yaşamaktadır." (Gökyay 2007: 941) Hikâyelerde bütün kahramanlar elinde kopuzuyla duygularını dillendirirler. Elinde kopuzu olan kişiye dokunulmaz; bu durum Türk inanç sisteminde kopuzun kutsal sayılmasıyla ilişkilidir. Kopuz, hikâyelerde çeşitli fonksiyonlar üstlenerek kahramanlar arasında iletişim sağlar.

"Dede Korkut Kitabında dikkati çeken unsurlardan biri de müzik aletleridir. Bunlardan adı en çok geçen kopuzdur. Dirse Han düşmana esir olduğu zaman karşıdan bir yiğidin geldiğini görür, bunun oğlu olduğunu bilmez. Onu yanına getirmek için kopuz çalar. Burada kopuz, tanınmayan birini davet eden bir vasıta olarak kullanılmıştır." (Kaplan 1979: 91)

Kopuz, kahramanların duygularını ifade etmelerini sağlayan bir alettir ve ozanlık geleneğiyle bir bütündür. Ozanlık sözlü gelenekle başlayan köklü bir gelenektir. Şiirler okuyan boy boylayan ozanlar, toplumun değer verip koruduğu şahsiyetlerdir. Ozan Türk millî kimliğini taşıyan özel ve kutlu kişi olan sanatçıdır. “Ozanlık geleneğinin, Türk edebiyatının ortaya çıkışıyla birlikte kültür tarihi içindeki yerini aldığı söylenebilir. Ayrıca, bu edebiyatın ilk ürünlerinden kabul edilen destan, sagu vb. mahsullerin ilk söyleyicilerinin de ozan vb. sanatçılar (kam, baksı, şaman, oyun) olduğu bilinmektedir." (Köprülü 1986: 49) Hikâyelerde özellikle Hikâyeleri tasnif eden kişi olduğu görüşü kabul gören Dede Korkut, Oğuznâme düzen, kopuz çalan, Bayındır Han'ın yanında özel bir yeri olan bir ozandır. Dede vasfı, Azerbaycan âşıklarının ozana verdiği bir vasıf olarak bilinir. 'Gelimli gidimli dünya, son ucu ölümlü dünya' deyişi baş ozan Dede Korkut'un her hikâyenin sonunda söylediği deyişidir. Dede Korkut, hikâyelerin sonunda kopuzuyla şiir söyler ve hem kahraman için hem Oğuz toplumu için dua eder. Dede

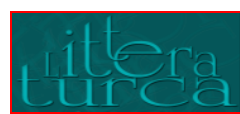

Journal of Turkish Language and Literature 
Korkut ozanların piri olarak kabul edilir ve Dede Korkut'un ozanlığı önem teşkil eder. Kopuzdan 'Dedem Korkut'un kopuzu' diye bahsedilir.

"Dede Korkut (Dedem Korkut, Korkut. Ata), bir bilge ozan, baş ozandır. Ozanların piridir. Usta ozandır. Bu sembol ozan var oluşundan itibaren geleneğe güç vermiştir geleneğin kendisinden güç aldığı Hep ozanların piri olarak kabul görmüştür. Hatta rüya motifinin birinci derecede önemli bir tipi olarak geleneğin sürdürülmesinde manevi destek olmuştur." (Günay 1992: 18-19)

Türk milleti tarihin her döneminde saza ve şiire önem vermiştir. Ozanların fonksiyonu o günden bu güne değişmemiş; değişen sadece isimleri ve çalgıları olmuştur. Âşık edebiyatının önemli ve temel özellikleri anlatılarda ilk/ezelî imge olma özelliği taşır. Türk kültüründe önemli bir gelenek olan âşık edebiyatının ilk şekli bu hikâyelerde çeşitli geleneklerle görülür. Saz eşliğinde irticalen söyleme, Beyrek'in düğüne “Deli Ozan” mahlasıyla gelmesi, Banı Çiçek ile atışması âşıklık geleneğinde önemli geleneklerdir.

“Oğuz Destanından parçalar okurlar ve Dede Korkut Hikâyelerini anlatırlar. Ozanlar, kolca kopuzlarını alıp ilden ile beyden beye gezerler. Onun içindir ki, ablası Beyrek'in haberini ozandan sorar: 'Mere Ozan, karşu yatan kara dağdan aşup geldügünde geçtüğünde Beyrek adlu bir yiğide buluşmadun mu?" (Gökyay 2007: 1107)

Hikâyelerin geçtiği coğrafya bugünde âşıklık geleneğin yoğun yaşandığı bölgelerdendir. Ozanlar, ilden ile dolaşan haberler getiren kişilerdir. Habercilik fonksiyonları ile kahramanlar arasında iletişim sağlama görevini üstlenirler.

"Dede Korkut'ta görülen başka bir ozan tipi de "gezici ozan"dır. Bu ozanın görevi, ilden ile obadan obaya, kaleden kaleye ya da evden eve haber taşımak iletişimi sağlamaktır. Böyle bir ozan sayesinde Bamsı Beyrek, Banı Çiçek'in başına gelenleri öğrenir, Yalancı oğlu Yaltacuk ile evleneceği haberini alır. Beyrek böyle bir ozanın kılığına girerek olayların üstesinden gelir ve lehine sonuçlanmasını sağlar. Bu tip ozanların kopuzu attan ve silahtan daha değerlidir." (Yakıcı 2007: 45)

Düğünlerde ozanlar gelir, şiir söyler, atışır. Beyrek, Banu Çiçek'in düğününe, deli ozan kılığıyla gelerek onunla atışır. Ozanların düğünlerde kopuzuyla şiir söylemesi o dönemden günümüze kadar sürmekte olan bir gelenektir.

\section{4. Şamanist ve İslâmî İnanışa Bağlı Gelenekler}

Hikâyelerde Türk inancını, İslâmiyet'in ve Gök Tanrı dininin birlikteliği şeklinde görürüz. Kahramanlar bir taraftan arı sudan abdest alır namaz kılar, öteki taraftan şarap içerler. Geçiş dönemi eseri olan Dede Korkut

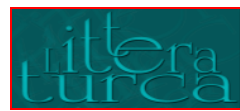

Journal of Turkish Language and Literature

Volume:4, Issue:1, Winter 2018, (17-35)

Doi Number: 10.20322/littera.378019 
Hikâyeleri bu bağlamda Türk insanının dinî inanışlarını geleneğe bağlı olarak yaşatma ülküsünü ve kültürel kodlarının sağlamlığını yansıtır.

“X.yüzyıl başlarında İslâmiyeti kabul etmeye başlayan ve XI. yüzyılın ilk yıllarında tamamiyle Müslüman olarak Horasan'a geçen Selçuk Oğuzları, Dede Korkut hikâyelerinden anlaşıldığına göre, XV. yüzyılda birçok Şamanizm geleneklerini muhafaza etmişlerdir(matem töreninde ölünün bindiği atın kuyruğunu keserek kurban etmek, aygır kesip 'aş' vermek, kurbanı-adağı nezir edenin çevresinde dolaştırmak, ağacı kutlu saymak ve bu gibi). Bu Oğuzlar'ın torunu olan bugünkü Anadolu Türkler'inde de eski inanç ve göreneklerin derin izlerine rastlanmaktadır." (İnan 1972: 207)

Bu durum, Türkler'in eski inanışlarını sürdürdüğünü, geleneklerinde yaşattığını, yeni dinlerine de uyarladıklarını gösterir. “íslâm dinini kabul etmiş olan Türkler ve diğer kavimler eski dinlerinden kalan birçok inanç, gelenek ve ayinleri yeni dinlerine sokmaya muvaffak olmuşlardır." (İnan 1972: 204) Animizm parelelliğini yansıtan hikâyelerde tabiat ana ile konuşma ve ona sığınma Şamanizm ve Gök Tanrı dininin anlatı düzleminde yansıyan gelenekleridir. Ağaç, su, dağ gibi tabiat unsurları kutsal iyelerdir. Kahramanlar dağa, ağaca ve suya seslenir. Özlemler ve arzular yüksek dağlarla iletişim kurularak dillendirilir. Dağın yüksek oluşu ve tabiat ana görevi kahramanların manzum kısımlarda sıkça dile getirdikleri bir durumdur. Beyrek, ağaçla konuşur; ona derdini anlatır.

Hikâyelerde İslâmî motiflerin yoğunluğu şekillenen gelenekler dikkat çekicidir. Anlatılarda, peygamberlerden, ehl-i beytten, Kur'an-ı Kerim'den vb. İslâmîyet dininin kutsal değerlerinden güçlü bir imanın ve inancın göstergesi olarak bahsedilir. Metinlerde kahramanlar dua ederken kurtuluş için İslâmiyet dininin kutsal ve yüce değerlerini vesile ederler.

"Begil oğlu Emren, babasına söylediği soylamada, yoldaşlığa, din-i Muhammet yoluna dürüşeyim senin içün' der. Kazılık Koca oğlu Yegenek hikâyesinde, Yegenek'in duasında geçen bütün unsurlar ile Begil oğlu Ermen'de geçen duanın bütün unsurları Kuran-ı Kerim'e dayanmaktadır. Bu duanın kimi dizeleri doğrudan ihlas, öteki adıyla 'Kul hüvallahu...' süresinden alınmadır." (Gökyay 2007: 989)

Kahramanlar zor anlarında inançlarından güç alarak dinî bir ritüeli gelenekselleştirirler. "Kahramanlar, felaket anında Allah'a sığınırlar. Basat, Tepegöz'ün gözünü kör ettiği sırada mağara içindedir. Koyun postuna girerek dışarıya çıkınca Tepegöz nasıl kurtulduğunu sorar. Basat, Tanrı’nın kendisini kurtardı̆̆ını söyler." (Elçin 1988: 29) Allah tarafından gönderilen Azrail, Emren'in düşmanını yenmesi için Allah’ın izniyle ona güç verir. Dede Korkut, İsmi Azam duasını okur Deli Karçal’ın eli asılı kalır. Kurbanlar duaların kabulü içindir; kurban sunma duaların kabulü için hem Şamanizm de hem de İslâmiyet'te ortak bir gelenektir. Günümüzde de Şamanizm etkileri İslâmiyet diniyle beraber sürmektedir. Hem Şamanizm inancında hem de İslâmiyet'te dualar manevi güç verir. Dede Korkut, Oğuz halkına dua eder uzun ömür ve kahramanlık ister. Ozan ağzından Bayındır Han ve Oğuz milleti için dua edilir. Dua koruyucu zırhtır ve negatifliği/olumsuzluğu yok eder. Kahramanlar, birbirleri için iyi

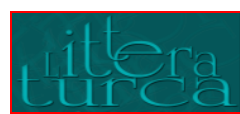

Journal of Turkish Language and Literature

Volume:4, Issue:1, Winter 2018, (17-35)

Doi Number: 10.20322/littera.378019 
dileklerde bulunarak dua ederler. Pay Piçen ve Pay Püre, beylerin ettikleri dua ile çocuk sahibi olur. Dirse Han, bir ağzı dualının hayır duasıyla çocuk sahibi olur. Eşlerin, annelerin, evlatların duaları kahramanı ayakta tutan ve ona güç veren dinî ritüellerdir.

Hem Şamanist hem de İslâmî inanış sistemi içinde inanışlarla şekillenen bir gelenek olarak rüya ve rüya yorumu öne çıkar. Türk kültüründe rüya, inanışlara bağlı anlam kazanan gelecekten haber verme, hayatı şekillendirme gibi özellikleriyle kutsal kabul edilen bir geleneğin değerlerini taşır. "Değişik toplumlarda tarihin çok eski dönemlerinden itibaren rastlanan rüya motifinin masal ve hikâyelerdeki durumu insan tabiatıyla ve insanın rüya olayı karşısındaki tutumuyla yakından ilgilidir." (Işık 2009: 48) Rüyanın mesajlarının doğru aktarımında yorumlanması önemlidir; rüya yorumu toplumun düşünüş kodlarını yansıtan bir uygulamadır. Uluğ Türk'ün gördüğü rüyayı, güzel duayla Oğuz’a anlatması ve Oğuz'un, vezirinin yorumunu beğenerek onun öğütlerini tutması kültürümüzde rüyanın ve rüya yorumunun önemini sergiler. “Gök Tanrı düşümde verdiğimi hakikate çıkarsın! Tanrım bütün yeryüzünü senin nesline bağışlasın (Sepetçioğlu 1995: 45) Hikâyelerde, Salur Kazan beylere rüyasını yorumlatır. 'Kara kuru düş gördüm' der. Bu bağlamda Salur Kazan'a rüya aracılığıyla gelecekte yaşayacağı felaket haber verilir. Yegenek'e, babasını kurtaracağı gördüğü rüyayla müjdelenir. Rüya ve rüya yorumu Gök Tanrı ve İslâmiyet dinlerinde önemsenen ve kutsal görülen kültürel bir özelliktir. Temelinde inanışlar etkilidir.

Dede Korkut Hikâyeleri'nde bütünsel bir şekilde Gök Tanrı ve İslâmiyet dininin şekillendirdiği inanış sistemi, kahramanların ve Oğuz toplumunun hayatına yön veren dinsel ritüelleri yaşatan geleneklerdir.

\section{Ad Verme Geleneği}

Ad, var olmadır; bu nedenledir ki insan hayata gözünü açar açmaz ona isim verilir. Bu değere bağlı olarak ad verme etrafında çeşitli gelenekler oluşur. Dede Korkut anlatısında geçiş aşamalarından olan ad alma geleneğinde iki unsur etkilidir. Kahraman, ya atasının adını alır veya kahramanlık göstererek ad almaya hak kazanır. Ata ile anılma, soyun devamını sağlama ve geleceğe kalma inancıyla bağlantılıdır. "Eski Türklerde soyadı, asıl addan önce söylenirdi. Duha Kocaoğlu, Deli Dumrul, Baydınoğlu Bakay Han, Yakıpoğlu Genç Manas, Ulaşoğlu Salur Kazan gibi." (Noyan 1983: 639) Atanın/babanın ismiyle anılma ad verme geleneğinde aile bütünlüğünün ve soyun devamının da bir göstergesidir. Geleneğe bağlı bir söylemle çocuk, aile ve toplum için gelecekte var olmaktır.

Hikâyelerde erkek kahramanlar yiğitlik göstermeden, hüner sergilemeden isim alamazlar. Dirse Han Oğlu Boğaç Han Hikâyesi'nde boğayı öldürdüğü için Boğaç Han adı Dede Korkut tarafından konulur. “Böyle ad alan çocuk, artık ailesinin ferdi olmaktan çıkar, cemiyetin kabilenin bir ferdi ilan edilirdi." (Noyan 1983: 640) Kahramanın isim almasında 15 yaş önemlidir. 15 yaş çocukluktan ergenliğe geçildiği dönemdir. Kişiliğin kazanıldığı karar verme gücünün ve olgunluğa geçişin sembolüdür. İsmini hak etmek için, baş kesmek, kan dökmek önemlidir. Beyrek, Bamsı ismini kan döküp baş keserek alır. Oğulun kahramanlık göstermesi baba için gurur kaynağıdır.

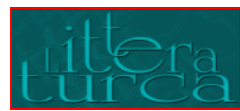

Journal of Turkish Language and Literature

Volume:4, Issue:1, Winter 2018, (17-35)

Doi Number: 10.20322/littera.378019 
Beyrek'in babası, bezirganların önce oğlunun elini öpmesine sinirlenir. Oğlunun tek başına kâfiri alt etmesi karşısında gururla Dede Korkut'u çağırıp ad vermesini ister. Alp ve gazi tipinin hikâyelerdeki görüntüsü kahramanlık göstermedir.

Dede Korkut gelir Oğuzname düzer ve ismini kahramana verir. 'adını ben verdim, yaşını Allah versin.' diye dua eder. “...Nitekim, Bamsı Beyrek (Böyrek) 15 yaşında 'kuş erdemlü bir güzel yiğit' olduğu halde henüz ad almamıştı. Nihayet 'baş kesti, kan döktü, adam ahtardı' ve bunun üzerine babası bir şölen tertip ederek bütün Oğuz beylerini çağırdı..." (Ülkütaşır 1963: 7) Ulu ve sözü geçen bir büyüğün isim vermesi geleneği, bugün de süren bir gelenektir. Kahramanlar adını hak ettiğini göstermek zorundadır.

\section{Renklere ve Sayılara Bağlı Gelenekler}

Bütün kültürlerde renklerin özel anlamları vardır ve renkler bir düşünceyi ifade ederek sembol diline dönüşür. Renklerin anlamları genelde evrenseldir; ancak kültüre bağlı olarak toplumlarda farklı anlam ve değerler kazanır. Bu bakımdan ayrı bir önem teşkil eden hikâyelerdeki renk sembolleri, evrensellik taşır. "Renk sıfatlarını büyük ustalıkla kullanan evrensel boyuttaki yapıtların arasına Dede Korkut'un da girmesi gerekiyor." (Karabaş 1996: 12) Dede Korkut anlatıları renklerin sembol anlamları ve olaylar arasındaki sağlam yapıyı tasvir eder.

Türk inancında siyah, beyaz, mavi ve kırmızı renklerin yönlere bağlı anlamları vardır. Mavi renk göğün rengi olarak doğuya ve saltanata karşılıktır. Manevi güç bağlamında 'görklü' gökyüzüne Tanrı́nın gücüne ve Ona yakın olmaya işarettir. Ak renk batıdır ve devlet yönetiminde bu yön devletin ikinci yönetim birimidir. Hikâyede çocuğu olmayan kişi kara çadıra oturtulur. Önüne kara koyun yahnisi konur. Oğlu olan ak otağa oturtulur ak koyun yahnisi verilir. Kızı olan da kızıl otağa oturtulur ve kızıl keçe serilir. Çocuksuzluğun Türk toplumunda lanet olarak görülmesi düşüncesi siyah renkle olumsuzluk taşıyan siyahla ifade edilir. Siyah renk kuzey yönlüdür ve karanlığı, soğuğu, yokluğu çağrıştırır. Hikâyelerde kara renk olumsuzluğu, kötüyü çağrıştıran bir anlam ifade eder. Beyrek'in kız kardeşleri karalara bürünür. Ak elbiselerini çıkarır mateme bürünür.

"Kara renginin hem gerçeği hem de gerçek hayattaki olumsuzlukları sembolize etmesi hikâyelerde birçok kavramla birlikte kullanılmasına da sebep olmuştur. Kara kaygılı rüyaların görülmesi ve yorumlanması; yas alametinin kara rengi ile nitelendirilerek verilmesi; keder, merak, endişe, acı gibi duyguların kara rengi ile somutlaştırılması ve sembolik göstergelerle açıklanması da örtülü iletişime örnektir. Yitirilen değerlerin temsili için kara rengi kullanılırken varoluşu temsil eden olumlu değerlere işaret etmek için de ak renginin kullanılması gerçek hayat içinde tezatların uyumuna dikkat çekmekte, karadan beyaza yani olumsuzluktan olumluya uzanan çizgiyi hatırlatmaktadır." (Çetindağ 2016: 389)

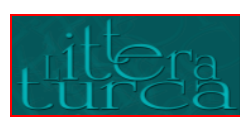

Journal of Turkish Language and Literature 
Ev ve otağın rengi yuvanın kutsallığını ve temizliği imleyen ak renktir. Ağ ban evler mutluluğun ve esenliğin sembolü olarak tasvir edilir. Olumluluk ve aydınlık anlamıyla güvenli bir yuvayı ağ/ak ban otağ/çadır sembolize eder. Ev ocaktır; ocağın ateşi ve dumanının tütmesi yönüyle ocak, aileye benzetilir. Kırmızı güney yönlüdür ve gücü, kuvveti, ateşi sembolize eder. Sıcak ve canlı olan kırmızı/al renk Dede Korkut'ta kadını, gücü, isteği ifade eder. "Kırmızı; gücün, bağımsızlığın, sevincin, bayramın ve koruyuculuğun sembolüdür. Ateş de kırmızıdır, onun için ailenin bir adı da ocaktır. Yani bir yönüyle kırmızı örtü, yeni kurulacak aile ocağının işaretidir." (Şimşek 2003: 146) Hikâyelerde kırmızı renk güç, ateş ve dişilik yönüyle kutsal yuvayı sembolize eder.

Neslin sürmesi ve gelecekte var olabilmenin şifresi, çoğalmada saklıdır. Bu ifade, aile olmanın temel şartının göçebe yaşamdaki önemini açıklar. Evlenenler kırmızı kaftan giyer; kırmızı renk gücü, bereketi ve murada ermeyi sembolize eder. “Dede Korkut Hikâyeleri'ndeki bilgiye göre Oğuzlarda güveylik elbise 'kırmızı kaftan', gelinlik ise Al duvaktır." (Rayman 2002: 13) Bu üç renk hikâyede yoğunluk kazanır. Selcen Hatun 'sarı donlu' olarak tasvir edilir. Sarı, Güneş'in rengidir ve Şamanist inançta merkezi ifade eder. Sarı renk, dişiyi ve merkezi sembolize eder; hükümdarlık işareti olarak da kullanılır. "Şamanizmden kaynaklanan görüş dünyanın merkezinin sembolü olarak sarı rengin kullanılmasıydı. Ülkenin sarayı, tahtı hep altın sarısı ile ifade edilmiştir. Bu renk aynı zamanda hükümdarlık olarak da kullanılmıştır." (www.ödevlistesi.com) Sarı Donlu Selcen Hatun, gücü ve güzelliğiyle diğer kadın kahramanlar gibi merkezî bir konumda eşinin yanında yer alan bir karakterdir. Sarı renkle tasvir edilişiyle güçlü kişiliği ve güzelliği ile anlatının merkezindedir.

Yeşil renk hayatın sembolüdür; baharın ve yeniden doğuşun sembolüdür. Bu anlamda Hızır, yeşil donlu/elbiseli olarak tasvir edilir. Tabiatın uyanışı nevruz, yeşilin/bitkinin ilk açışıyla kutlanır. Anlatım birimlerindeki olay örgüsüne göre renkler anlam kazanır. Olumlulukta ve olumsuzluktaki renkler farklıdır. Olaydaki karşıtlığa bağlı olarak renkler de karşıtık kazanır. Renklerin dili bugün de halk kültüründe yaygındır.

Sayılar, kültürel kimlikle ve inanışlarla şekillenerek uygulamalara ve anlatılara yansır. Devamlılık ve hatırlatılma işleviyle edebî metinler sayıların etrafında teşekkül eden inanışları geleneğe dönüştürür. Sayı formelleri bir, üç, yedi, dokuz, ve kırk sayıları edebiyatımızda oldukça çok görülen kültürel belleğin izdüşümü olan geleneği yansıtan motiflerdir. Dede Korkut anlatıları da sayı formelleri bakımından kültürel kodla oluşan bir zenginliğe sahiptir. Kan Turalı üç canavarla savaşır. Kahramanlık ritüellerinin bir geleneği olan av, yedi gün yedi gece sürer, esaretler yedi yıl sürer. Beylerin uykusu yedi gün sürer, bu uyku küçük ölüm olarak değerlendirilir. Beyrek otuz dokuzuncu gün evine gelir ve kırkıncı gün olayların çözüme kavuşur. Kahramanların yanında kırk yiğit ve kırk ince belli kız vardır. Düğünler kırk gün kırk gece sürer. Kırk sayısı gizem ve güç anlamında olgunluk tamlıktır, bu bağlamda Hz. Muhammed kırk yaşında peygamberlikle müjdelenir. Çilehanede kalma süresi kırk gündür. Bu sayıları halk arasında yaşatılan birçok gelenekte görmekteyiz. Kırklamalar, dinî ve ezotorik ritüeller olarak kırk sayısının hayatın geçiş aşamalarında doğumdan, evlenmeye ve ölüme kadar uygulanan çeşitli arınmalardır. Anlatılarımızda ortak bir motif olan sayı formelleri belli fonksiyonları üstlenir.

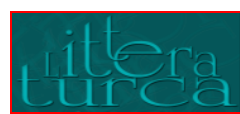

Journal of Turkish Language and Literature 


\section{Atasözleri ve Deyimlerle İlgili Gelenekler}

Atasözleri, halk/toplum tecrübesine dayanan millî kimliği yansıtan bir formdur. Geleneklerin kültürel bellekte oluşma kodları arasında atasözü ve deyimler de vardır. Türk insanının hayat tecrübesini ve bilgeliğini taşıyan değerli sözlerdir. Az sözle çok şey anlatmak istediğimizde, bir olayı açıklarken hep 'atalarımızın dediği gibi' ifadesini kullanırız. Hayat tecrübesinin sözcüklerle şifrelenmesi olan atalar sözü, tecrübeleri yansıtan bir gelenekle doğar ve bu yönüyle geleceğe taşınır. Dede Korkut Hikâyeleri'nin Mukaddime kısmında ozanın söylediği her atasözü ataların tecrübeleriyle onaylanmıştır. Yine giriş kısmında atasözlerinin bu kadar geniş yer tutması Türk insanının atalarının tecrübesine verdiği önemin tezahürüdür.

Anonim olan bu sözler, ilk söyleyicileri unutularak; halkın atalardan kalan ortak mirası olmuştur. Atalar tecrübesinin belleği kısacık bir cümleye, geniş ve derin bir anlam yüklenir. Dede Korkut Hikâyeleri'nde özellikle Dede Korkut'la bütünleşen, günümüzde de benzer ya da aynı şekilde kullanılan atasözleri vardır. 'Eski panbuk bez olmaz', 'Ezelden yazılmazsa kul başına bela gelmez.' Kız anadan görmeyince ögüt almaz.' Oğul atadan görmeyince sufra çekmez.' vb. atasözleri millî hafızanın yaşamsal alanıdır. 'At ayağı külüg, ozan dili çevük olur' uzun zamanı kısaltma anlamının yanında atın ve ozanın çabuk hareket etmesi gerektiğini belirtir. Atasözleri tavsiye, nasihat ve uyarı içerir. Gelecek nesillere atalarının deneyimlerini ulaştıran atasözleri, iletişimi sağlayan bir unsurdur. Türk dilinin zengin kelime hazinesini ve işlevsel bir dil olma özelliğini gösterirler.

Deyimler, bir durumu ifade eden özlü sözlerdir. Uzun bir hayat tecrübesinin kelimelerde saklanmasıdır. Dede Korkut Hikâyeleri'nde deyimlere baktığımızda: 'melül olmak', üzüntülü bir hali 'kara giyinmek', yaslı olmayı 'feryat kılmak', çektiği acıyı haykırmayı 'başını koymak', bir şey uğruna canını vermeyi ifade eder. Birlikte yaşamanın ve ortaklığın mahsulü deyimler, ince anlamlar taşır. “Ortak bir halk dili ve zevki ile ancak birkaç cümle kalıbı içinde meydana gelebilen bu mahsullerin kolaylıkla aşılmayan sağlam birer bünyeleri vardır. " (Elçin 1988: 340) Dede Korkut'ta geçen atasözü ve deyimler, uzun tecrübeleri, yaşanmışlıkları kısa ve yoğun anlatımlarla geleceğe aktararak ışık tutan geleneği yansıtan özlü sözlerdir.

\section{Av ve Yağma Geleneği}

Göçebe toplumlarda av, bir yaşam tarzıdır. Gelenek, bir süreci kapsar, kuralları ve ilkeleri zamanla oluşur. Türk toplumunun güç bir coğrafyada yaşaması, avcılığı beraberinde getirir. “Avcılık, Türklerde günümüzden çok eski zamanlara kadar giden bir geleneğe sahiptir. İnsanlık tarihinin ilk dönemlerinden itibaren avcılığın temel bir hayat tarzı olarak, beslenme ile doğrudan bağlantısı da akla gelen bir gelenektir." (Güven-Hergüner 1999: 34) Orta Asya toprakları bozkır yaşamıyla şekillenen bir coğrafyadır. Yaşanılan coğrafya şartları ve geçmiş kültür bunu gerekli kılar. Doğa şartlarına karşı ayakta kalmanın tek yolu güçlü ve savaşçı karaktere sahip olmaktır. Illk dönemler avcılık, yaşamı sürdürmek için yapılan bir eylemdi.

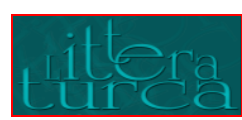

Journal of Turkish Language and Literature

Volume:4, Issue:1, Winter 2018, (17-35)

Doi Number: 10.20322/littera.378019 
Oğuz insanı çocukların eğitiminde av ve okçuluğa ayrı bir önem vermiştir. "Bulundukları yer ve yaşadıkları doğal koşulların zorluğuna alışmak ve çocukları da ona göre yetiştirmek gerektiğinden kız ve erkek çocuklarını ok atma avlanma ve ata binme eğitimine tabi tutarlardı." (Güven-Hergüner 1999: 33) Erkek çocuğun ilk avı önemlidir; buna bağlı olarak anneler, evladının ilk avını toy düzenleyerek kutlar. Av maharet gösterme meydanıdır, bu bağlamda babalar için oğulun ava katılması gurur kaynağıdır. Beyler, birlikte yılda bir defa Bayındır Han'ın başkanlığında av töreni yapar ve törenden sonra av paylaşımı yapılır. Avdan pay alma/isteme bir gelenektir; Banı Çiçek'in yengesi Beyrek'in avından pay ister. Av ve sürü kültürü, göçebe Türk toplumunda yaşanılan coğrafyanın gerekli kıldığı bir özelliktir. Avın beraberinde toy düzenlenir ve beylerle halk hep birlikte ziyafete katılırlar. Av, savaşa hazır olma adına eğitim özelliğine sahiptir. "Salur Kazan Oğuz Beyleri'ne yata yata yanumuz ağrıdı, dura dura belümüz kurudu. Yürüyelim a begler, av avlayalum, kuş kuşlayalum, sığın geyik yıkalum diyor ve hepsi atlanıp ava çıkıyorlar. Bunların kimi sürek avlarıdır." (Gökyay 2007: 1034)

Yağmalama/yağmalatma geleneği beylerin, halkına sunduğu gönül rızasıyla dağıttığı mallarını dağıtma törenidir. Bey olmanın ve halkını düşündüğünün göstergesi olan bu gelenek, gönül zenginliğini ve paylaşımı ortaya koyar. Saçı geleneğiyle bağlantılı olarak kansız kurbana da örnektir. Tanrı'nın yeryüzündeki elçisi olan yöneticiler, ihsan ederek halkını mutlu etme bilinciyle töreyi canlı tutar.

"Saçı (libation), 'yalma (ağaçlara ve şaman davuluna bağlanan paçavralar), tös (ongon)ları yedirme (ağızlarını yağlama), ateşe yağ atma ve şarap serpme gibi törenler kansız kurbanlardır. Kansız kurbanların en önemlisi ruhlara bağışlanarak başıboş salıverilen hayvanlardır. Bu türlü kurbana eski Türkler (ıdık) yahut (ıduk) demişlerdir." (Inan 1972: 98)

Beylik, halkına/milletine sahip çıkma ve onlara sunulan ikramla özdeşleştirilir. "Dede Korkut hikâyelerinde Kazan Bey'in üç yılda bir İç-Oğuz ve Dış-Oğuz beylerini bir araya getirdiği, onları topladıktan sonra evini yağmalattığı anlatılmaktadır." (Güleç 2002: 383) Hatta Dış Oğuzların yağmaya çağrılmaması savaş sebebi olmuştur. Bu gelenek Türk Beylerinin kazandığını paylaşma düşüncesiyle ve hediye verme geleneğiyle bağlantılıdır. Beylerin yılda bir kez evlerini yağmalatması hediye sunma ve saçı geleneklerini içerir. "Kazan Beg'ün adeti bu idi ki kaçan Kazan evini yağmalatsa helalinün elini alır evinden taşra çıkarıdı; andan evinde olan esbabını ve malını yağma ederleridi." (Gökyay 2007: 187) Yağma geleneği Türk beylerinin halkını koruması, doyurması düşüncesiyle ilişkilidir. Yağma/yağmalatma töreni biz duygusunun tezahürü ile toplumsal bağların güçlendiği bir gelenektir.

\section{Düğün ve Toy Geleneği}

Evlilik, insan hayatında geçiş dönemleri içinde dönüm noktalarından biridir. Geleneklerin uygulanışı milleti diğer toplumlardan ayıran kültürel bir özelliktir. "işte bundan dolayı, örf, âdet, gelenek ve göreneklerin canlı bir şekilde yaşatıldığı 'geçiş dönemleri', bir milleti başka milletlerden ayıran kültürel değerlerin başında gelir."(Şimşek 2003: 135) Bamsı Beyrek anlatısı, evlilik adetleri bakımından zengin bir anlatıdır. Evlenme

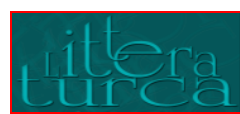

Journal of Turkish Language and Literature

Volume:4, Issue:1, Winter 2018, (17-35)

Doi Number: 10.20322/littera.378019 
adetlerine baktığımızda ilk dikkati çeken gelenek 'beşik kertmesi' geleneğidir. Bu gelenek, Türk kültüründe devam eden bir gelenektir. Beyrek ve Banu Çiçek doğmadan önce aileler arasında verilen sözle beşik kertmesi geleneği uygulanır. Bir çeşit ant olan bu gelenekle Beyrek ve Banı Çiçek'in babaları aralarında çocuklarını birbirleriyle evlendirmek için sözleşir.

Kızın istenmesi sırasında, uygulanan geleneklerde toplumun saygı duyduğu, söz sahibi olan kişi/kişiler aracılığıyla isteme merasimi gerçekleştirilir. Dede Korkut, Oğuz toplumunun yüce bilicisi olarak kız isteme geleneğini yerine getirir. Deli Karçar’ın şart koştuğu istekler bugün halkın yaşattığı ve sürdürdüğü süt hakkı, kalın/başık gibi geleneklerin ilk şeklidir.

Yiğitler, evleneceği genç kızı seçerken alp tipini yansıtan eş adayı için yolculuğa çıkar. Kadın kahramanlar da eşlerinde aynı meziyetleri arar. Kan Turalı evleneceği kızın kendisinden daha üstün olması gerektiğini belirtir ve babası ona uygun eşin Selcen Hatun olduğunu söyler. "Kan Turalı aydur: Baba men yerümden durmadın ol durmış ola; men Karakoç atuma binmedin ol binmiş ola; men kanlu kâfir eline varmadın ol varmış, mana baş getürmiş ola, dedi. Kanlı Koca aydur: Oğul sen kız istememişsin, bir cılasun bahadır istemişsin..." (Gökyay 2007: 121) Erkek kahramanlar evlenebilmek için imtihandan geçerler. Banu Çiçek ile Beyrek güreşirler, ok atarlar ama birbirlerine galip gelemezler. Banu Çiçek'in ağabeyi Deli Karçar, Beyrek'i imtihana tabi tutar. Kan Turalı Selcen Hatun için babasının imtihanından geçer. Bu özellikler evlenilecek eşin meziyetlerini görmek içindir. Bu gelenek de günümüzde yaşatılmaktadır.

Evlenen eşler al kaftan giyer, gerdek çadırı kurulur ve çadırın rengi aldır. Al renkli kaftan ve çadır, murad almayı/evlenmeyi ve sevdiğine kavuşmayı sembolize eder. Eğlenceler düzenlenir ve düğünler kırk gün kırk gece sürer. Oğuz beyleri ve halk hep birlikte ozanların eşliğinde eğlenir. Attan aygır deveden buğra koyundan koç kesilir. Güreş, cirit atma, ok atma gibi müsabakalar düzenlenir.

Toy geleneği çeşitli vesilelerle düzenlenen eğlencelerin adıdır. Büyük zaferler, sürek avları sırasında halk hep birlikte eğlenir. Toy ve yemek, toplum içinde saygınlık göstergelerinden olan geleneklerdir. "Sofra ise, misafirperverliğin, cömertliğin, yoksul doyurmanın, hayırseverliğin ve paylaşımcılığın bir göstergesi olarak simge değerdir." (Deveci 2016: 31) Bu törenler millet olmanın, coşkunun, birlik olmanın, gücün doruk noktalara ulaştığı, geleneğin dirildiği kültürel bellek mekânlarıdır. Anlatılarda beyler ve hanımları evlatlarının zaferlerini ulu toylar düzenleyerek kutlar. “Proto-Türk gelenekleri, konuk aşı ile konuk evini, boy veya kabilenin, atasından gelen, bir miras olarak görmüşlerdi. Bunun için misafiri ağırlama, topluluğun müşterek bir vazifesi gibi kabul ediliyordu." (Ögel 1988: 315) Dede Korkut bu toyların onur konuğudur ve toplumu birleştiren ulu kişidir. Tören boyunca iyilik ve hayır duaları yapılır.

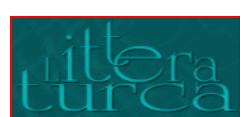

Journal of Turkish Language and Literature 


\section{SONUÇ}

Gelenek ve göreneklerimizin birçoğunun ilk şekilleri, Dede Korku Hikâyeleri'nde geçer. Şamanist ve İslâmî inanışların geleneğe bağlı izdüşümüyle sosyal hayatı şekillendirdiği, kahramanların eylemlerini belirlediği ve günümüzde de izlerinin devam ettiği görülür. Türk halkı, devlet adamlarına bağlı, değerleri için yaşayan, atasına ve soylu geçmişine sahip çıkan bir topluluktur. Hikâyelerde bireysel duruştan toplum olma bilincine uzanan millî bir karakter vardır. Kahraman/kahramanlar, düşmanına boyun eğmeyen atasına töresine bağlı, özü sözü bir olan, inançlı bir şekilde biz düşüncesiyle hareket eden bireyleşmiş Türk milletinin birer ferdidir. Yüce birey Dede Korkut, Oğuz halkının atası ve babasıdır. Ata ve babanın değeri anlatıda dikkat çekicidir. Aile olma, evlat sahibi olma ve çoğalma önemli değerlerdir. Dede Korkut anlatılarının kahramanları, töresini bilen, değerlerine bağlı, soylu bir nesildir. Kişiler, iyilik, yiğitlik ve kahramanlık bağlamında birleşirler. Anlatılar kültürel belleği içine alan bir mekânla/evrenle aynı değerler etrafında birleşir. Bu evrenin/mekânın düşünce iklimine hoşgörü, sevgi ve paylaşma duyguları egemendir. Ad verme geleneği, evlenme adetleri, vb. gelenekler kültürel belleği canlı tutan değerler bütünüdür. Dede Korkut Hikâyeleri kültür hayatımızın değeri yorumlandıkça artan eseridir. Millet olma bilincinin ülkü değerler düzeyinde anlatıldığı Türk kahramanlık destanı, Dede Korkut Hikâyeleri, kültür mozağimizin kıymetli bir eseridir. Dede Korkut Hikâyeleri tecrübe, kimlik ve hatırlatma özelliği taşıyan geleneklerin/uygulamaların, canlı tutulması ve geleceğe aktarımında kültürel bellek mekânı değerine sahip zengin anlatılardır.

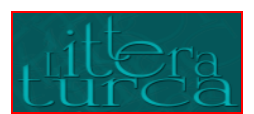




\section{KAYNAKÇA}

Aktulum, Kubilay (2013). Folklor ve Metinlerarasılık, Çizgi Kitabevi Ankara.

Assmann, Jan (2001). Kültürel Bellek (Çev. Ayşe Tekin), Ayrıntı Yayınları, İstanbul.

Çetindağ, Gülda Süme (2016); “Dirse Han Oğlu Boğaç Han ile Kam Püre'nin Oğlu Bamsı Beyrek Destanı'ndaki Sembolik Göstergeler", III. Uluslararası Türk Dünyası Kültür Kongresi Dede Korkut ve Türk Dünyası Bildiriler Kitabı, 19-23 Ekim, Çeşme-İzmir 2015, C. I, s. 382-395.

Deveci, Mutlu (2016). “Sosyal Psikoloji Açısından Dirse Han Oğlu Boğaç Han Boyu Anlatısında Kolektif Davranış Belirleyicileri", Dede Korkut Okumaları (Editör: Ramazan Korkmaz), Kesit Yayınları, İstanbul.

Elçin, Şükrü (1988). Halk Edebiyatı Araştırmaları 2, Kültür Ve Turizm Bakanlığı Yayınları, Ankara.

Eröz, Mehmet (2000). Türk Ailesi, Milli Eğitim Bakanlığı Yayınları, Bilim Ve Kültür Eserleri Dizisi, İstanbul.

Fordham, Frieda (2004). Jung Psikolojisinin Ana Hatları (Çev. Aslan Yalçıner),Say Yayınları, İstanbul.

Gökyay, Orhan Şaik (2007). Dedem Korkut'un Kitabı, Akçağ Yayınları, Ankara.

Güleç, Hamdi (2002). Halk Edebiyatı, Çizgi Yayınları, Konya.

Günay, Umay (1992). Türkiye'de Âşık Tarzı Şiir Geleneği Ve Rüya Motifi, Akçağ Yayınları, Ankara.

Güven, Özbay-Gülten Hergüner (1999). “Türk Kültüründe Avcılığın Temel Dayanakları”, Pamukkale Ü. Eğitim Fakültesi Dergisi, S. 5, s. 32-49.

Işık, Neşe (2009). Türk Masallarının Sembolik Açıdan Çözümlenmesi, Doktora Tezi Elazığ: Fırat Üniversitesi İnan, Abdülkadir (1972). Tarihte ve Bugün Şamanizm, Türk Tarih Kurumu Basımevi, Ankara.

Kanter, M. Fatih (2005). “Dede Korkut Hikâyelerinin Arketipsel Sembolizm Yöntemiyle Çözümlenmesi," Arayışlar, Yıl: 7, S. 14, S. 131-138.

Kaplan, Mehmet (1999). Türk Edebiyatı Üzerinde Araştırmalar, C.1, Dergah Yayınları, İstanbul.

Karabaş, Seyfi (1996). Dede Korkut'ta Renkler, Yapı Kredi Yayınları, İstanbul.

Korkmaz, Ramazan (2016). “Arketipsel Sembolizm Açısından Dede Korkut Anlatılarındaki Yüce-Birey ve Alp-Bilge Tipi”, Dede Korkut Okumaları (Editör: Ramazan Korkmaz), Kesit Yayınları, İstanbul.

Köprülü, Fuat (1986). Edebiyat Araştırmaları, Türk Tarih Kurumu Yayınları, Ankara.

Noyan, Bedri (1983). “Ad Vermede Gelenekler-Türkçe İnsan Ve Aile Adları Hakkında”, Türk Kültürü, Yıl: XXI, Ekim, Sayı: 246, S. 638-650.

Ögel, Bahaeddin (1988). Dünden Bugüne Türk Kültürünün Gelişme Çağları, Türk Dünyası Araştırmaları Vakfı, İstanbul.

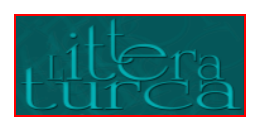

Journal of Turkish Language and Literature 
Rayman, Hayrettin (2002). “Nevruz Ve Türk Kültüründe Renkler”, Milli Folklor, Yıl: 14, S.53, Bahar, C.7, S. 10-15.

Sepetçioğlu, Mustafa Necati (1992). Karşılaştırmalı Türk Destanları, İrfan Yayınları, İstanbul.

Şimşek, Esma (2003). "Kadirli ve Sumbas(Osmaniye)'ta Evlenme Âdetleri”, Folklor/Edebîyat, C.9, S. 34, s.135155.

Türköne, Mualla (1995). Eski Türk Toplumunun Cinsiyet Kültürü, Ark Yayınevi, Ankara.

Ülkütaşır, M. Şakir (1963). "Türklerde Ad Verme Ille İlgili Âdet Ve İnanmalar”, Türk Kültürü, S.10, Ağustos, s.712.

Ünlü, Mahir (1994). Dede Korkut Öyküleri, İnkılap Yayınları, İstanbul.

Yakıcı, Ali (2007). “Dede Korkut Kitabı’nda Görülen Ozan Tiplerinin Türkiye Sahası Âşıklık Geleneğinin Oluşumuna Etkisi”, Milli Folklor, Yıl: 19, S. 73, C. 10, S. 40-47.

\section{Yararlanılan internet siteleri}

www. Ödevlistesi.Com

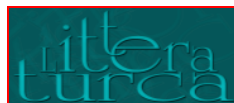

